\title{
DINAMIKA PENULARAN PENYAKIT DEMAM BERDARAH DENGUE (DBD) DI WILAYAH KERJA PUSKESMAS MUNGKID KABUPATEN MAGELANG TAHUN 2015
}

\author{
Farida Kusuma Wardani $^{1)}$, Aris Santjaka ${ }^{2)}$, Budi Utomo ${ }^{3)}$ \\ Jurusan Kesehatan Lingkungan, Politeknik Kesehatan Kemenkes Semarang, \\ Jl.Raya Baturaden KM 12 Purwokerto, Indonesia
}

\begin{abstract}
Abstrak
Peningkatan kasus dan sebaran yang semakin meluas di wilayah kerja Puskesmas Mungkid dapat digambarkan dengan dinamika penularan. Penelitian ini bertujuan mengetahui dinamika penularan penyakit Demam Berdarah Dengue (DBD) di wilayah kerja Puskesmas Mungkid Kabupaten Magelang yang meliputi model penularan dan determinan pada tahun 2015. Jenis penelitian ini termasuk penelitian observasional dan didasarkan pada dokumentasi catatan Puskesmas Mungkid Tahun 2015. Hasil Penelitian karakteristik penderita DBD tertinggi yaitu pada kelompok pendidikan dasar (51,85\%), serta puncak waktu serangan pada Bulan Februari. Jenis kasus indigenus sebanyak 34 kasus dan 20 kasus import dengan model penularan terbanyak berupa separated yaitu 16 separated sedangkan cluster sebanyak 9 cluster. Serta kondisi lingkungan yang nyaman bagi nyamuk dengan cahaya, suhu, dan kelembaban masingmasing dengan rata-rata 4,09 lux; 80,22\%; dan 29,15 ${ }^{\circ}$ C. Curah hujan tertinggi pada Bulan Februari yaitu 27,52 mm/hari dengan jumlah hari hujan sebanyak 19 hari dalam sebulan. Kesimpulan ditemukan 9 model penularan cluster, keterlambatan penyelidikan epidemiologi menambah jumlah kasus empat kali lebih besar dibandingkan awal kasus. Saran sebaiknya PSN dilaksanakan satu bulan berturut-turut mengikuti surveillance puncak DBD.
\end{abstract}

Kata kunci:Dinamika penularan; model; determinan

\begin{abstract}
The Transmission Dynamics of Dengue Haemorrhagic Fever (DHF) in Local Government Clinic of Mungkid Magelang 2015. Increased cases and widespread distribution in Puskesmas Mungkid can be described with the transmission dynamics. This study aims to determine the dynamics of disease transmission Dengue Hemorrhagic Fever (DHF) in Mungkid local government clinic of Magelang regency that includes model and determinants of transmission in 2015. This study is an observational study and based on the documentation of the health center records Mungkid 2015. Results patient characteristics DBD highest in the group of primary education (51.85\%), and the peak time of the attack in February. Indigenus types of cases as many as 34 cases and 20 cases imported by mode of transmission most be separated while the cluster is 16 separated by 9 clusters. As well as a comfortable environment for mosquitoes with light, temperature, and humidity each with an average of 4.09 lux; $80.22 \%$; and $29.15^{\circ} \mathrm{C}$. The highest rainfall in February is $27.52 \mathrm{~mm} /$ day by the number of rainy days as much as 19 days a month. Conclusions found 9 models of transmission clusters, epidemiological investigation delays increase the number of cases is four times larger than the beginning of the case. Suggestions should be implemented PSN consecutive month following the peak dengue surveillance.
\end{abstract}

Keywords:The transmission dynamics; mode; determinant

\footnotetext{
1) E-mail: faridawardani@yahoo.co.id

${ }^{2)}$ E-mail: Arissantjaka@gmail.com

3)E-mail: Budut17@yahoo.co.id
}

\section{Pendahuluan}

Penyakit Demam Berdarah Dengue (DBD) mulai dikenal di Indonesia sejak tahun 1968 di Surabaya dan Jakarta, setelah itu jumlah kasus DBD terus 
bertambah seiring dengan semakin meluasnya daerah endemis DBD. Penyakit ini tidak hanya sering menimbulkan KLB tetapi juga menimbulkan dampak buruk sosial maupun ekonomi. Kerugian sosial yang terjadi antara lain karena menimbulkan kepanikan dalam keluarga, kematian anggota keluarga, dan berkurangnya usia harapan hidup penduduk (Kemenkes, 2012).

Data Dinas Kesehatan Kabupaten Magelang tahun 2015 menunjukkan bahwa penderita DBD tertinggi berada di wilayah kerja Puskesmas Mungkid yaitu sebanyak 54 penderita. Penyakit DBD setiap tahun selalu terjadi peningkatan dan sebaran yang semakin meluas sebenarnya dapat digambarkan dengan dinamika penularan. Dinamika penularan digunakan untuk mengetahui riwayat sebaran penyakit, model sebaran, dan determinannya. Disinilah kelebihan dinamika penularan yang dapat digunakan oleh petugas kesehatan untuk membuat perencanaan penanggulangan penyakit sehingga KLB dapat diminimalisir. Tujuan penelitian ini adalah untuk mengetahui dinamika penularan penyakit DBD di wilayah kerja Puskesmas Kabupaten Magelang tahun 2015.

\section{Bahan dan Metode}

Penelitian ini dilaksanakan di wilayah kerja Puskesmas Mungkid Kabupaten Magelang. Wilayah kerja Puskesmas Mungkid luas wilayahnya mencapai 3171,92 Ha yang terdiri dari 14 desa. Semua wilayahnya merupakan daerah dataran rendah dengan rata-rata ketinggian 350,7 mdpl (Profil Puskesmas Mungkid, 2015).

Populasi dalam penelitian ini adalah seluruh penderita DBD di wilayah kerja Puskesmas Mungkid sepanjang tahun 2015 berjumlah 54 penderita. Sampel dalam penelitian ini adalah seluruh populasi kasus yaitu semua penderita DBD di wilayah kerja Puskesmas Mungkid yaitu sebanyak 54 penderita.

Cara pengumpulan data yaitu berupa :

a. Wawancara terhadap kasus dilakukan untuk mengetahui tempat terjadinya penularan di lingkungan tempat tinggal (indigenus) atau di luar lingkungan tempat tinggal (import) menggunakan lembar kerja.

b. Penghitungan larva index berdasarkan hasil Penyelidikan Epidemiologi (PE) oleh petugas dari Puskesmas Mungkid dan pengukuran cahaya, suhu serta kelembaban.

c. Pemetaan kasus dengan Global Positioning System (GPS).

d. Dokumentasi yaitu untuk mendapatkan data sekunder berupa data umum mengenai Kecamatan

Mungkid dan data curah hujan melalui Dinas Pekerjaan Umum Kabupaten Magelang.

Analisis data dilakukan deskriptif dengan melihat hasil tampilan peta grafik antar variabel (overlay) dengan aplikasi ArcView GIS Version 3.1 yaitu penemuan kasus DBD dengan curah hujan. Serta grafik dan tabel silang untuk menggambarkan hasil penelitian.

\section{Hasil dan Pembahasan}

1. Karakteristik Penderita DBD di Wilayah Kerja Puskesmas Mungkid Kabupaten Magelang Tahun 2015

Data Puskesmas Mungkid tahun 2015 diperoleh angka penderita DBD sebanyak 54 kasus. Adapun uraiannya seperti dibawah ini:

a. Karakteristik Penderita Berdasarkan Umur

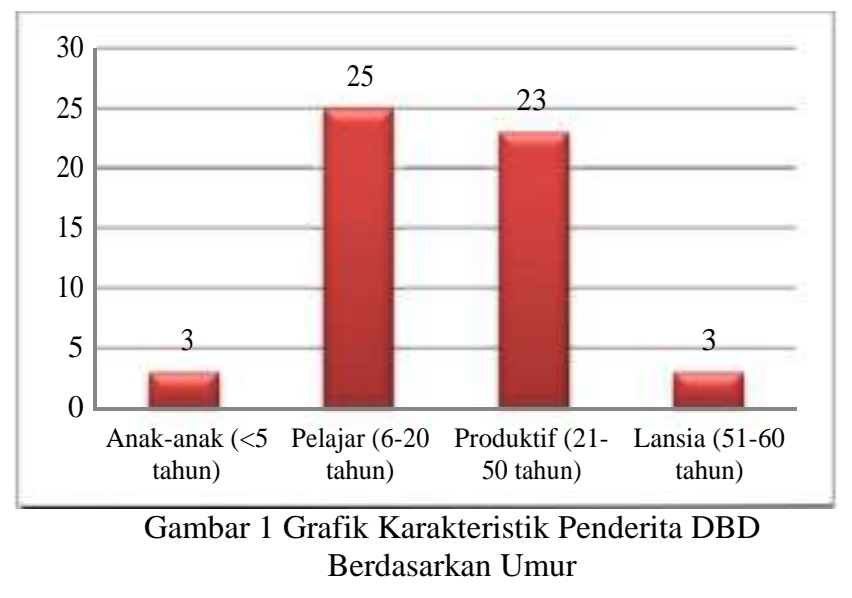

Hasil penelitian yang dijelaskan dalam gambar 1 menunjukkan bahwa kasus DBD menurut kelompok umur tertinggi pada kelompok umur pelajar (6-20 tahun) yaitu sebanyak 25 orang $(46,3 \%)$ sedangkan jumlah penderita terendah pada kelompok anak-anak ( $<5$ tahun) dan lansia (51-60 tahun) dengan jumlah masing-masing 1 orang $(5,6 \%)$.

Umur merupakan salah satu karakteristik yang dapat mempengaruhi kondisi suatu masalah kesehatan atau penyakit, karena umur sangat berpengaruh terhadap tingkat keterpaparan besarnya resiko serta sifat resisten tertentu (Bustan \& Arsunan, 1997).

Penyakit demam berdarah dengue (DBD) dapat menyerang semua golongan umur, namun sampai saat ini demam berdarah dengue lebih banyak menyerang anak-anak, tetapi dalam dekade terakhir ini terlihat kecenderungan kenaikan proporsi kelompok dewasa. Meskipun penyakit demam berdarah dengue menyerang segala usia, beberapa penelitian menunjukkan bahwa anak-anak lebih rentan tertular, salah satunya adalah karena faktor imunitas (kekebalan) yang relatif lebih rendah dibandingkan orang dewasa (Ginanjar, 2008). 
b. Karakteristik Pendidikan

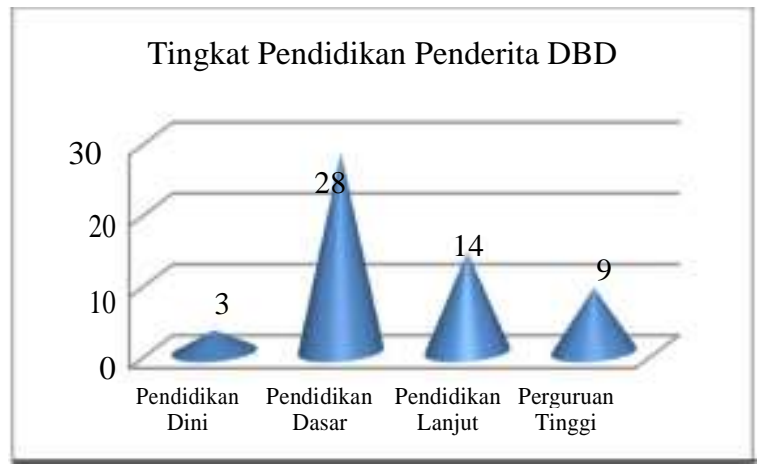

Gambar 2 Grafik Pendidikan Penderita DBD

Tingkat pendidikan penderita DBD tertinggi yaitu pada kelompok pendidikan dasar dengan persentase sebesar 51,85\% sedangkan terendah yaitu kelompok pendidikan dini sebesar 5,55\%.

Pendidikan akan berpengaruh cara berpikir dalam mencegah dan pemberantasan serta penularan dari penyakit DBD. Terbentuknya perilaku baru pada seseorang dimulai darimengenal terhadap stimulus yang berupa materi atau obyek diluarnya sehingga menimbulkan pengetahuan baru pada seseorang tersebut.Pengetahuan merupakan hasil tahu, dan ini terjadi setelah orang melakukan penginderaan terhadap obyek tertentu melalui panca indera manusia.Pengetahuan responden mengenai DBD, vektor penyebabnya serta faktor yang mempengaruhi keberadaan jentik nyamuk Aedes aegypti sangat diperlukan untuk mencegah terjadinya penularan penyakit DBD serta menekan perkembangan dan pertumbuhan jentik nyamuk Aedes aegypti (Yudhiastuti dkk, : Idharmawan dkk., 2015).

c. Karakteristik Penderita Berdasarkan Jenis Kelamin

Tabel 1 Jenis Kelamin Penderita DBD

\begin{tabular}{cccc}
\hline No. & $\begin{array}{c}\text { Jenis } \\
\text { Kelamin }\end{array}$ & Jumlah & $(\%)$ \\
\hline 1. & Laki-laki & 28 & 51,9 \\
2. & Perempuan & 26 & 48,1 \\
\hline & Jumlah & 54 & 100 \\
\hline
\end{tabular}

Jumlah seluruh penderita DBD yaitu 54 penderita DBD tahun 2015 di wilayah kerja Puskesmas Mungkidproporsinya lebih banyak laki-laki yaitu sebesar $51,9 \%$ sedangkan perempuan sebanyak $48,1 \%$.

Distribusi kasus berdasarkan jenis kelamin pada tahun 2008 persentase penderita laki-laki dan perempuan hampir sama. Jumlah penderita berjenis kelamin laki-laki adalah 10.463 orang $(53,76 \%)$ dan perempuan berjumlah 8.991 (46,23\%) (Soepardi Jane, 2010 dalam Buletin Jendela Epidemiologi).

Hasil penelitian terdahulu yang telah dilakukan terhadap karakteristik penderita DBD menurut jenis kelamin menunjukkan bahwa risiko terkena DBD untuk laki-laki dan perempuan hampir sama, tidak tergantung jenis kelamin.

d. Karakteristik Penderita Berdasarkan Jenis Pekerjaan

Tabel 2 Jenis Pekerjaan Penderita DBD

\begin{tabular}{llcc} 
No & \multicolumn{1}{c}{ Jenis Pekerjaan } & Jumlah & $(\%)$ \\
& & & \\
\hline 1. & Belum bekerja & 3 & 5,6 \\
2. & Pelajar atau mahasiswa & 23 & 42,6 \\
3. & PNS & 2 & 3,7 \\
4. & Swasta & 21 & 38,9 \\
5. & Buruh & 9 & 9,2 \\
\hline \multicolumn{2}{r}{ Jumlah } & 54 & 100 \\
\hline
\end{tabular}

54 penderita DBD tahun 2015 di wilayah kerja Puskesmas Mungkid apabila dikelompokkan berdasarkan jenis pekerjaannya, persentase penderita terbanyak adalah kelompok pelajar atau mahasiswa sebesar42,6\% sedangkan penderita terendah yaitu dengan jenis pekerjaan sebagai PNS sebesar 3,7\% seperti yang tercantum pada tabel 2 .

Pekerjaan di tingkat pelajar lebih sering dikarenakan sering terpapar oleh vektor penular penyakit DBD. Vektor penular banyak bersarang di kolam bangku pelajar, kolom kursi pelajar serta di lingkungan kebun dan halaman tempat para siswa bermain. Selain itu, waktu aktifitas siswa dalam belajar, bermain sama dengan waktu siklus dari vektor penular, hal ini menyebabkan tergigit vektor penular lebih sering. Uraian tersebut jelas dikatakan bahwa pekerjaan di tingkat pelajar sangat tinggi untuk angka kejadian DBD (Budianto dkk. : Idharmawan dkk., 2015).

e. Karakteristik Umur dengan Pendidikan

Tabel 3 Karakteristik Umur dengan Pendidikan

\begin{tabular}{llccccc}
\hline & & \multicolumn{5}{c}{ Pendidikan } \\
\cline { 3 - 6 } No. & $\begin{array}{c}\text { Kelompok } \\
\text { Umur }\end{array}$ & Dasar & Lanjut & $\begin{array}{c}\text { Pendidikan } \\
\text { Tinggi }\end{array}$ & $\begin{array}{c}\text { Pra } \\
\text { Sekolah }\end{array}$ & Total \\
\hline 1. & Anak-anak & 0 & 0 & 0 & 3 & 3 \\
2. & Pelajar & 14 & 6 & 5 & 0 & 25 \\
3. & Produktif & 12 & 7 & 4 & 0 & 23 \\
4. & Lansia & 2 & 1 & 0 & 0 & 3 \\
\hline & Total & 28 & 14 & 9 & 3 & 54 \\
\hline
\end{tabular}


Kelompok umur anak-anak berusia kurang dari 5 tahun, kelompok umur pelajar antara 6-20 tahun, kelompok umur produktif antara 21-50 tahun, dan kelompok umur lansia antara 51-60 tahun. Berdasarkan tabel 3 didapatkan bahwa penderita DBD tertinggi yaitu pada kelompok pendidikan dasar dengan kelompok umur pelajar sebanyak 14 penderita.

Penyakit demam berdarah dengue (DBD) dapat menyerang semua golongan umur, namun sampai saat ini demam berdarah dengue lebih banyak menyerang anak-anak, tetapi dalam dekade terakhir ini terlihat kecenderungan kenaikan proporsi kelompok dewasa. Meskipun penyakit demam berdarah dengue menyerang segala usia, beberapa penelitian menunjukkan bahwa anak-anak lebih rentan tertular, salah satunya adalah karena faktor imunitas (kekebalan) yang relatif lebih rendah dibandingkan orang dewasa (Ginanjar, 2008).

Seperti yang dinyatakan Yudhiastuti dkk dalam penelitian Idharmawan dkk bahwa pendidikan akan berpengaruh cara berpikir dalam mencegah dan pemberantasan serta penularan dari penyakit DBD Terbentuknya perilaku baru pada seseorang dimulai dari mengenal terhadap stimulus yang berupa materi atau obyek diluarnya sehingga menimbulkan pengetahuan baru pada seseorang tersebut Pengetahuan merupakan hasil tahu, dan ini terjadi setelah orang melakukan penginderaan terhadap obyek tertentu melalui panca indera manusia.

Pengetahuan responden mengenai DBD, vektor penyebabnya serta faktor yang mempengaruhi keberadaan jentik nyamuk Aedes aegypti sangat diperlukan untuk mencegah terjadinya penularan penyakit DBD serta menekan perkembangan dan pertumbuhan jentik nyamuk Aedes aegypti.

Teori diatas cukup menjelaskan bahwa penyakit DBD di wilayah kerja Puskesmas Mungkid keterkaitannya antara umur dan pendidikan tertinggi yaitu pada kelompok pendidikan dasar dengan kelompok umur pelajar. Aktivitas kesehariannya di sekolah merupakan peluang lebih besar tertular DBD mengingat Aedes aegypti aktif menghisap darah pada siang hari (diurnal) dengan dua puncak gigitan yaitu jam 08.00-09.00 dan jam 16.00-17.00 menurut (Christophers dalam Upik Kesumawati dkk., 2012).

2. Sebaran Penderita DBD di Wilayah Kerja Puskesmas Mungkid Kabupaten Magelang Tahun 2015

a. Model Penularan

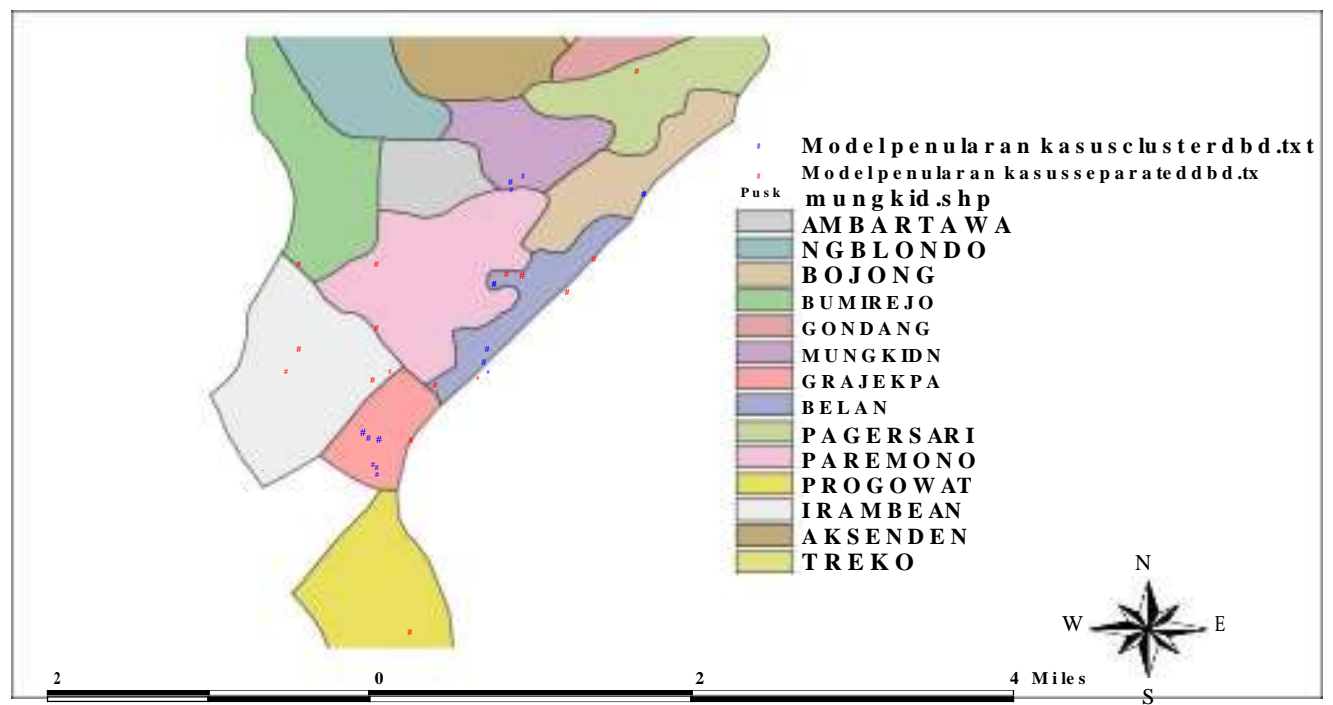

Gambar 3 Peta Model Dinamika Penularan DBD

Cluster yaitu penularan Demam Berdarah Dengue (DBD) tempat kejadian kasus pertama dengan kasus lainnya berjarak \pm 100 meter dari penderita pertama. Sedangkan sparated yaitu penularan Demam Berdarah Dengue (DBD) tempat kejadian kasus pertama dengan kasus lainnya berjarak lebih dari 100 meter dari penderita pertama (Purnomo A, 2010, h.48). Berdasarkan gambar 3 
terdapat 9 model penularan cluster dan 16 model penularan separated.

Penyebaran nyamuk Aedes aegypti betina dewasa dipengaruhi oleh beberapa faktor termasuk ketersediaan tempat bertelur dan darah, tetapi tampaknya terbatas sampai jarak 100 meter dari lokasi kemunculan. Transportasi pasif dapat berlangsung melalui telur dan larva yang ada dalam penampung (WHO, 2001).

Model penularan berupa cluster dan separated disebabkan oleh jarak terbang nyamuk yang terbatas yaitu sampai jarak 100 meter, kecuali nyamuk tersebut mengalami transportasi pasif yaitu mengikuti transportasi manusia sehingga berpindah ke daerah lain tanpa harus terbang dengan jarak yang jauh sehingga hal ini memberikan peluang terjadinya kasus dengan model separated.

Selain disebabkan oleh jarak terbang nyamuk, model penularan juga disebabkan oleh sanitasi yang buruk sebagaimana disampaikan oleh Umar Fahmi, 2012 bahwa faktor kependudukan mempengaruhi proses penularan atau pemindahan penyakit dari satu orang ke orang lain. Kepadatan juga akan mempengaruhi produksi sampah atau limbah yang akhirnya berdampak buruk terhadap manusia itu sendiri. Lingkungan dengan sanitasi yang buruk biasanya terdapat banyak barang-barang yang dipakai maupun tidak terpakai di sekitar lingkungan rumah sehingga akan menambah tempat perkembangbiakan nyamuk apabila barang-barang tersebut menampung air.

Model penularan berupa cluster sebanyak 9 kasus cluster disebabkan karena potensi penularan yang didapatkan melalui kegiatan penyelidikan epidemiologi oleh petugas dari Puskesmas Mungkid didapatkan berada dibawah standar yang seharusnya. Angka Bebas Jentik (ABJ) berdasarkan hasil penyelidikan epidemiologi yaitu $90,71 \%$. Seperti yang dijelaskan WHO (Kusumaningrum S, 2013, h.19), bahwa suatu daerah dikatakan mempunyai kepadatan dan penyebaran vektor yang rendah untuk penularan $\mathrm{DBD}$, jika nilai $\mathrm{ABJ} \geq 95 \%$. Berdasarkan teori tersebut maka hasil ABJ 90,71\% termasuk mempunyai kepadatan dan penyebaran vektor yang tinggi sehingga peluang terjadinya penularan DBD dengan model cluster besar.

b. Jenis Kasus

Sebanyak 54 penderita DBD di wilayah kerja Puskesmas Mungkid setelah dilakukan wawancara lalu dicatat dalam lembar kerja didapatkan dua jenis kasus penderita yaitu kasus import dan indigenus. Ditemukan 20 kasus import dan 34 kasus indigenus atau besar perbandingannya sebesar 10:17.

Di Kota Makassar mobilitas penduduk berperan dalam penyebaran $\mathrm{DBD}$, hal ini disebabkan mobilitas penduduk di kota Makassar yang relatif tinggi. Sesuai dengan Sumarmo bahwa penyakit biasanya menjalar dimulai dari suatu pusat sumber penularan (kota besar), kemudian mengikuti lalu lintas (mobilitas) penduduk. Semakin tinggi mobilitas semakin besar kemungkinan penyebaran
penyakit
DBD
(Arsunan
dkk.:

Respository.usu.ac.id).

Hujan akan mempengaruhi naiknya kelembaban nisbi udara dan menambah jumlah tempat perkembangbiakan (breeding places). Curah hujan yang lebat menyebabkan bersihnya tempat perkembangbiakan vektor oleh karena jentiknya hanyut dan mati.Kejadian penyakit yang ditularkan nyamuk biasanya meninggi beberapa waktu sebelum musim hujan lebat atau setelah hujan lebat. Pengaruh hujan berbeda- beda menurut banyaknya hujan dan keadaan fisik daerah. Terlalu banyak hujan akan

menyebabkan kekeringan, mengakibatkan berpindahnya tempat perkembangbiakan vektor akan berkurang, tetapi keadaan ini akan segera pulih cukup bila keadaan kembali normal. Curah hujan yang cukup dengan jangka waktu lama akan

memperbesar kesempatan nyamuk untuk berkembang biak secara optimal (Depkes, 2007).

Jenis kasus yang terdapat di wilayah kerja Puskesmas Mungkid yaitu 20 kasus import dan 34 kasus indigenus. Mobilitas penduduk yang tinggi dengan curah hujan yang ada sangat berpengaruh terhadap jenis jenis kasus yang terjadi seperti dijelaskan pada teori diatas. Curah hujan tertinggi terletak pada bulan Februari yaitu sebesar 27,52 $\mathrm{mm} /$ hari dengan jumlah hari hujannya 19 hari hal itu tergolong curah hujan yang cukup dengan jangka waktu yang lama sehingga akan memperbesar kesempatan nyamuk untuk berkembangbiak secara optimal.

c. Hasil Penyelidikan Epidemiologi (PE)

Tabel 4 Rentang Waktu Dilaksanakannya Penyelidikan Epidemiologi Sejak Penderita Mulai Sakit DBD

\begin{tabular}{ccccc}
\hline No & $\begin{array}{c}\text { Nama } \\
\text { Responden }\end{array}$ & $\begin{array}{c}\text { Tanggal } \\
\text { Mulai } \\
\text { Sakit }\end{array}$ & $\begin{array}{c}\text { Tanggal } \\
\text { Dilaksanakan } \\
\text { PE }\end{array}$ & $\begin{array}{c}\text { Rentang } \\
\text { Waktu }\end{array}$ \\
\hline 1. & SH & $18 / 04 / 2015$ & $06 / 05 / 2015$ & 18 hari \\
2. & YK & $18 / 06 / 2015$ & $27 / 06 / 2015$ & 9 hari \\
3. & RS & $18 / 07 / 2015$ & $25 / 07 / 2015$ & 7 hari \\
4. & WD & $6 / 08 / 2015$ & $24 / 08 / 2015$ & 18 hari \\
5. & MY & $15 / 08 / 2015$ & $03 / 09 / 2015$ & 19 hari \\
6. & DA & $18 / 08 / 2015$ & $22 / 08 / 2015$ & 4 hari \\
7. & MD & $27 / 08 / 2015$ & $05 / 09 / 2015$ & 9 hari \\
8. & GF & $28 / 08 / 2015$ & $03 / 09 / 2015$ & 6 hari \\
9. & AM & $10 / 09 / 2015$ & $26 / 09 / 2015$ & 16 hari \\
\hline
\end{tabular}

Rentang waktu dilaksanakannya penyelidikan epidemiologi sejak penderita mulai 
sakit DBD oleh petugas Puskesmas Mungkid paling lama yaitu 19 hari sedangkan paling cepat yaitu 4 hari dengan rata-rata rentang waktu yang diperlukan sekitar 12 hari seperti yang dijelaskan pada tabel 4 .

Permenkes RI No.1501/Menkes/Per/X/2010 tentang Jenis Penyakit Menular Tertentu yang

Menimbulkan Wabah menyatakan bahwa penyelidikan epidemiologi desa atau kelurahan yang mengalami KLB dilakukan dalam waktu kurang dari 24 jam. Berdasarkan rata-rata waktu kurang dari 24 jam pelaksanaan PE penyakit DBD di wilayah kerja Puskesmas Mungkid termasuk dalam kategori terlambat sehingga ditemukan kasus lain sebanyak 4 orang penderita dari jumlah total 9 penderita yang dilakukan penyelidikan epidemiologi. Oleh karena itu, perlu adanya teknologi penegasan terhadap seseorang yang positif menderita DBD kurang dari 24 jam dikarenakan sejauh ini waktu yang digunakan untuk penegasan memerlukan waktu yang cukup lama sehingga semakin menambah lama waktu dilaksanakannya penyelidikan epidemiologi.

3. Hasil Pengukuran Variabel Lingkungan Penderita DBD di Wilayah Kerja Puskesmas Mungkid Kabupaten Magelang Tahun 2015

Makhluk hidup termasuk didalamnya nyamuk sangat tergantung pada kondisi lingkungan, apabila kondisi lingkungan optimal, maka perkembangannya akan cepat, dengan demikian memperbesar kontak dengan manusia, dampaknya risiko penularan semakin besar (Singer M, 2009 dalam Dachlan YP, 2010 dalam Santjaka A, 2013). a. Curah Hujan dan Jumlah Penderita DBD

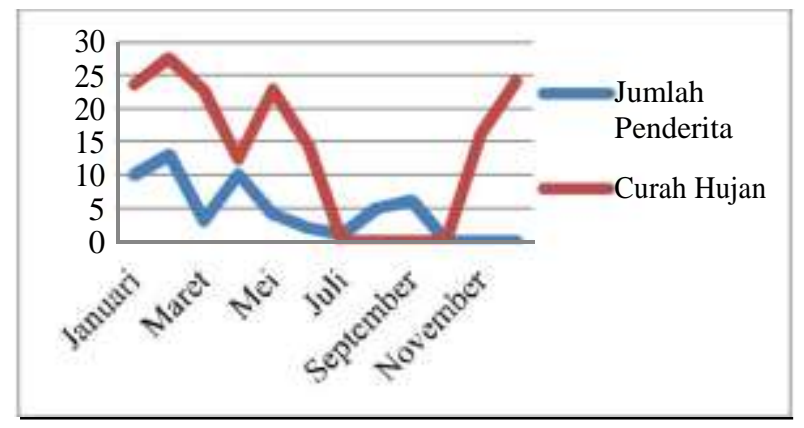

Gambar 4 Grafik Curah Hujan dan Jumlah Penderita DBD

Gambar diatas menggambarkan bahwa pada Bulan Februari terjadi puncak kasus DBD (13 penderita) yang diiringi dengan curah hujan yang cukup tinggi juga yaitu sebesar 27,62 mm/hari dengan jumlah hari hujan sebanyak 19 hari.

Hujan akan mempengaruhi naiknya kelembaban nisbi udara dan menambah jumlah tempat perkembangbiakan (breeding places). Curah hujan yang lebat menyebabkan bersihnya tempat perkembangbiakan vektor oleh karena jentiknya hanyut dan mati. Kejadian penyakit yang ditularkan nyamuk biasanya meninggi beberapa waktu sebelum musim hujan lebat atau setelah hujan lebat. Pengaruh hujan berbeda-beda menurut banyaknya hujan dan keadaan fisik daerah. Terlalu banyak hujan akan

menyebabkan kekeringan, mengakibatkan berpindahnya tempat perkembangbiakan vektor akan berkurang, tetapi keadaan ini akan segera pulih cukup bila keadaan kembali normal. Curah hujan yang cukup dengan jangka waktu lama akan

memperbesar kesempatan nyamuk untuk berkembang biak secara optimal (Depkes, 2007).

Gambar 4 diatas menunjukkan bahwa terjadi fluktuasi antara jumlah penderita dengan curah hujan, terjadi puncak kasus pada Bulan Februari saat curah hujan cukup dengan jumlah hari hujan 19 hari. Curah hujan yang cukup dengan jangka waktu lama akan memperbesar kesempatan nyamuk untuk berkembang biak secara optimal sehingga persebaran penyakit DBD terjadi peningkatan. Pada Bulan Juni dan Juli terjadi kenaikan kasus DBD meskipun curah hujan nol atau tidak ada hujan sama sekali. Hal ini disebabkan karena masih adanya jentik nyamuk Aedes sp yang breeding placesnya berada di dalam rumah seperti pada pot bunga, tampungan air dispenser, tampungan air almari pendingin dan sebagainya.

b. Hasil Pengukuran Intensitas Cahaya (Lux)

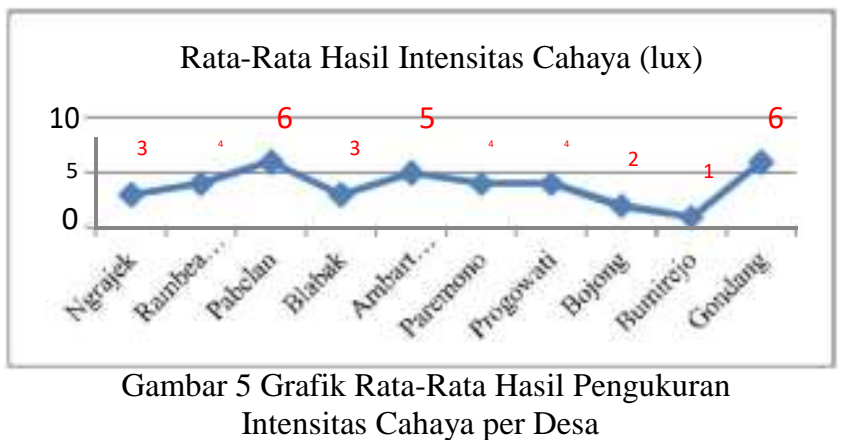

Hasil pengukuran pada gambar 5 menunjukkan bahwa dari 54 rumah penderita DBD tahun 2015 di wilayah kerja Puskesmas Mungkid yang dilakukan pengukuran intensitas pencahayaan didapatkan hasil antara 1 lux hingga 28 lux atau rata-rata intensitas cahayanya 4,09 lux. Hasil pengukuran intensitas cahaya tersebut tergolong redup atau rendah.

Nyamuk mempunyai kesukaan atau kebiasaan beristirahat di tempat yang gelap dan lembab (Sucipto Cecep Dani, 2011).

Berdasarkan teori tersebut, maka hasil pengukuran pencahayaan yang dilakukan berpeluang 
besar menjadi tempat kesukaan nyamuk untuk beristirahat dikarenakan tempatnya gelap dan lembab.

c. Hasil Pengukuran Kelembaban (\%)

Rata-Rata Hasil Pengukuran Kelembaban (\%)

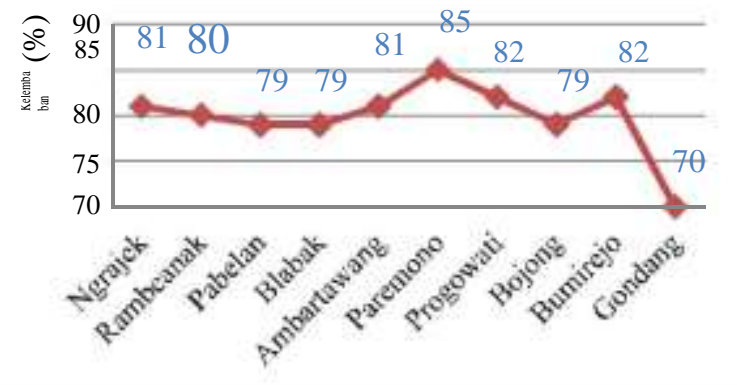

Gambar 6 Grafik Rata-Rata Hasil Pengukuran Kelembaban per Desa

Hasil pengukuran kelembaban pada gambar 6 menunjukkan bahwa dari 54 rumah penderita DBD tahun 2015 di wilayah kerja Puskesmas Mungkid yang dilakukan pengukuran kelembaban didapatkan hasil antara $74 \%$ hingga $86 \%$ atau rata-rata $80,22 \%$.

Pada kelembaban kurang dari $60 \%$ umur nyamuk akan menjadi pendek sehingga tidak cukup untuk siklus pertumbuhan parasit di dalam tubuh nyamuk (Depkes, 2007). Lingkungan resting atau tempat beristirahat nyamuk yang baik memenuhi beberapa persyaratan antara lain kelembaban cukup tinggi, teduh, suhu relative rendah, dan sedikit matahari (Santjaka A, 2013).

Hasil pengukuran yang telah dilakukan tersebut menunjukkan angka yang cukup tinggi sehingga sesuai dengan kebutuhan nyamuk untuk beristirahat. Hasil pengukuran kelembaban yang tinggi juga disebabkan oleh padatnya pemukiman penduduk berdasarkan observasi saat wawancara peneliti terhadap responden.

Seperti yang dinyatakan Sanovi A (dalam Santjaka A, 2013) bahwa kelembaban sangat tergantung iklim mikro, hal ini berpengaruh pada kebiasaan nyamuk untuk menggigit apakah di dalam atau di luar rumah, pada kondisi iklim yang ekstrim akan berpengaruh pada kebiasaan menggigit dan beristirahat nyamuk betina.

Hasil pengukuran suhu, kelembaban, dan pencahayaan menurut teori diatas bahwa kelembaban sangat tergantung dengan iklim mikro. Iklim mikro terdiri dari banyak komponen termasuk suhu dan pencahayaan. Gerakan thorax dan abdomen ketika nyamuk aktif merupakan pompa yang memventilasi bagian luar sistem trachea, sehingga spiracle terbuka, aktifitas nyamuk jika terbang terlalu jauh kebutuhan oksigen tidak terpenuhi, sehingga gerakan ventilasi (keluar masuknya $\mathrm{O}_{2}$ dan $\mathrm{CO}_{2}$ ) ditingkatkan untuk menutup kekurangan oksigen maka kehilangan air akan lebih besar, karena proses evaporasi, hal ini lebih parah jika kondisi udara kering (suhu meningkat) yang berdampak pada kelembaban rendah, kehilangan air akan terjadi dalam jumlah besar, dengan demikian mortalitas nyamuk akan jauh lebih banyak karena dehidrasi (Edbas, 2010 dalam Santjaka A, 2013).

d. Hasil Pengukuran Suhu $\left({ }^{\circ} \mathrm{C}\right)$

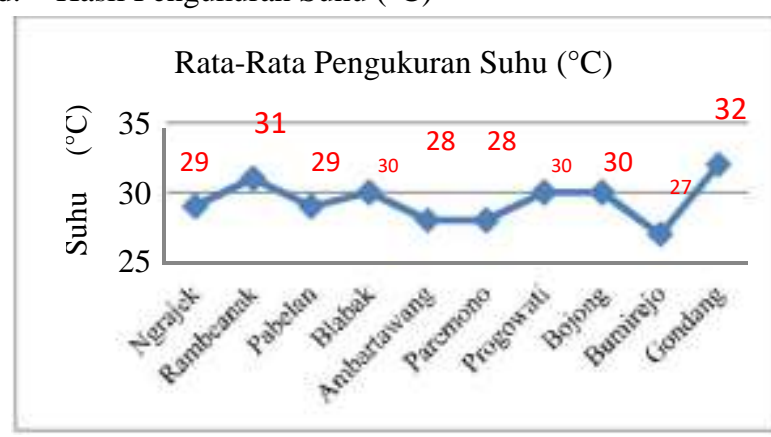

Gambar 7 Grafik Rata-Rata Hasil Pengukuran Suhu per Desa

Hasil pengukuran suhu pada gambar 7 menunjukkan bahwa dari 54 rumah penderita DBD tahun 2015 di wilayah kerja Puskesmas Mungkid yang dilakukan pengukuran suhu didapatkan rata-rata $29,15^{\circ} \mathrm{C}$.

Nyamuk tidak dapat mengatur suhu tubuhnya. Suhu rata-rata optimum untuk perkembangan nyamuk adalah $25^{\circ}-27^{\circ} \mathrm{C}$ nyamuk dapat bertahan hidup dalam suhu rendah, tetapi proses metabolismenya menurun atau bahkan terhenti bila suhu turun sampai dibawah suhu kritis pada suhu yang sangat tinggi akan

mengalami perubahan proses fisiologisnya. Pertumbuhan nyamuk akan terhenti sama sekali bila suhu kurang dari $10^{\circ} \mathrm{C}$ atau lebih dari $40^{\circ} \mathrm{C}$. Toleransinya terhadap suhu tergantung pada spesies nyamuknya, tetapi pada umumnya suatu spesies tidak akan tahan lama bila suhu lingkungan meninggi $5^{\circ}-6^{\circ} \mathrm{C}$ diatas, dimana spesies secara normal dapat beradaptasi (Depkes, 2007).

Kecepatan perkembangan nyamuk tergantung dari kecepatan proses metabolisme sebagian diatur oleh suhu. Oleh karena kejadian-kejadian biologis tertentu seperti lamanya masa pendewasaan,

kecepatan pencernaan darah yang dihisap, pematangan indung telur, frekuensi mencari makanan atau menggigit, dan lamanya pertumbuhan parasit didalam tubuh nyamuk dipengaruhi oleh suhu (Depkes, 2007).

Hasil pengukuran suhu pada rumah responden tergolong melebihi suhu optimum namun nyamuk 
masih dapat berkembangbiak meskipun tidak dengan suhu optimum. Apabila suhu lingkungan meninggi $5^{\circ}$ $6^{\circ} \mathrm{C}$ dapat menghambat pertumbuhan parasit di dalam tubuh nyamuk sehingga perkembangbiakan nyamuk tertekan atau menurun.

4. Indikator Potensi Penularan DBD di Wilayah Kerja Puskesmas Mungkid Kabupaten Magelang Tahun 2015

a. Hasil Perhitungan Container index (CI)

Hasil penyelidikan epidemiologi (PE) yang dilakukan oleh petugas Puskesmas Mungkid terhadap beberapa penderita DBD tahun 2015 didapatkan hasil CI sebesar 0,965\%. Hasil tersebut menurut WHO daerah tersebut

dikatakan mempunyai kepadatan dan penyebaran vektor yang rendah untuk penularan DBD karena nilai $\mathrm{CI}<5 \%$.

b. Hasil Perhitungan House Index (HI)

Hasil penyelidikan epidemiologi (PE) yang dilakukan oleh petugas Puskesmas Mungkid terhadap beberapa penderita DBD tahun 2015 didapatkan hasil HI sebesar 9,29\%. Hasil tersebut menurut WHO daerah tersebut

dikatakan mempunyai kepadatan dan penyebaran vektor yang rendah untuk penularan DBD karena nilai $\mathrm{HI}<10 \%$.

c. Hasil Perhitungan Breteu Index (BI)

Hasil penyelidikan epidemiologi (PE) yang dilakukan oleh petugas Puskesmas Mungkid terhadap beberapa penderita DBD tahun 2015 didapatkan hasil BI sebesar 8,82\%.Hasil tersebut menurut WHO daerah tersebut dikatakan tidak berpotensi mengalami KLB DBD karena BI $<50$ per seratus rumah.

d. Hasil Perhitungan Angka Bebas Jentik (ABJ) Hasil penyelidikan epidemiologi (PE)

yang dilakukan oleh petugas Puskesmas Mungkid terhadap beberapa penderita DBD tahun 2015 didapatkan hasil ABJ sebesar 90,71\%.Hasil tersebut menurut WHO daerah tersebut dikatakan mempunyai kepadatan dan penyebaran vektor yang tinggi untuk penularan DBD karena nilai $\mathrm{ABJ} \leq 95 \%$.

\section{Kesimpulan}

Jumlah kasus DBD tahun 2015 berjumlah 54 kasus yang terdistribusi di 10 desa wilayah kerja

Puskesmas Mungkid Kabupaten Magelang. Karakteristik penderita DBD terbanyak yaitu pada kelompok umur pelajar, kelompok pendidikan dasar, kelompok jenis kelamin laki-laki, kelompok jenis pekerjaan sebagai pelajar atau mahasiswa, serta puncak waktu serangan pada Bulan Februari.
Radius sebarannya yaitu 32 kasus berjarak lebih dari 100 meter dari indeks kasus serta 22 kasus berjarak kurang dari 100 meter dari indeks kasus.

Dugaan determinan berupa CI 0,965\%; HI 9,29\%; BI 8,82\%; dan ABJ 90,71\%. Rata-rata hasil pengukuran variabel lingkungan intensitas cahata 4,09 lux, suhu $29,15^{\circ} \mathrm{C}$, kelembaban $80,22 \%$, serta puncak curah hujan tertinggi yaitu pada Bulan Februari sebesar 27,62 mm/hari dengan jumlah hari hujan sebanyak 19 hari pada bulan tersebut juga terjadi puncak kasus DBD pada tahun 2015 di wilayah kerja Puskesmas Mungkid Kabupaten Magelang.

Model penularan berupa cluster sebanyak 9 cluster dan separated sebanyak 16 separated. Jenis kasus berupa import dan indigenus sebanyak 20 kasus import dan 34 kasus indigenus.

Saran sebaiknya PSN dilaksanakan satu bulan berturut-turut mengikuti surveillance puncak DBD. Penelitian lebih lanjut diperlukan mengenai hubungan mobilitas penduduk dengan separated DBD di wilayah kerja Puskesmas Mungkid.

\section{Ucapan Terimakasih}

Terima kasih disampaikan kepada Puskesmas Mungkid Kabupaten Magelang, Jurusan Kesehatan Lingkungan, dosen pembimbing skripsi Politeknik Kesehatan Kemenkes Semarang serta pihak-pihak yang terkait sehingga penelitian ini dapat terlaksanakan.

\section{Daftar Pustaka}

AchmadiU.F, 2012, Manajemen Penyakit Berbasis Wilayah Edisi Revisi, Jakarta:Rajawali Pers.

Allo Kurniasary R, 2015, Karakteristik Penderita Demam Berdarah Dengue Pada Dewasa Di Rumah Sakit Universitas Hasanuddin Periode

1 Januari-31 Desember 2014, Makassar :Universitas Hasanuddin.

Bustan dan Arsunan, 2002, Pengantar Epidemiologi, Makassar:Penerbit Rhineka Cipta.

Dinas Kesehatan Kabupaten Magelang, 2015, Data Kasus DBD Lima TahunTerakhir, Bidang P2PL, Dinas Kesehatan Kabupaten Magelang.

Departemen Kesehatan Republik Indonesia, 1986, Demam Berdarah Diagnosa dan Pengelolaan Penderita, Jakarta:Departemen Kesehatan Republik Indonesia.

Departemen Kesehatan Republik Indonesia, 2005, Pencegahan dan Pemberantasan Demam Berdarah Dengue di Indonesia, Jakarta:Direktorat Jenderal Pengendalian Penyakit dan Penyehatan Lingkungan, Departemen Kesehatan RI.

Departemen Kesehatan Republik Indonesia, 2007a, Ekologi dan Aspek Perilaku Vektor, Jakarta:Direktorat Jenderal Pengendalian 
Penyakit dan Penyehatan Lingkungan,

Departemen Kesehatan RI.

Departemen Kesehatan Republik Indonesia, 2007b, Survay Entomologi Demam Berdarah Dengue, Jakarta:Direktorat Jenderal Pengendalian Penyakit dan Penyehatan Lingkungan, Departemen Kesehatan RI.

Departemen Kesehatan Republik Indonesia, 2013, Profil Kesehatan Indonesia 2012, Jakarta:Departemen Kesehatan RI.

Departemen Kesehatan Republik Indonesia, 2014, Modul Pengendalian Demam Berdarah Dengue, Jakarta:Departemen Kesehatan RI.

Ginanjar, 2008, Demam Berdarah Dengue, Jakarta: PT Bentang Pustaka.

Idhawarman B L dkk, 2015, Gambaran Karakteristik dan Angka Kejadian Pasien Demam Berdarah Dengue Di RS Al-Ihsan Tahun 2014,Bandung:Universitas Islam Bandung.

Kusumaningrum S, 2013, Densitas Larva Aedes.spp di Desa Pliken Kecamatan Kembaran Kabupaten BanyumasTahun 2013, Purwokerto :Politeknik Kesehatan Kemenkes Semarang.

M. Sabir dan Rosa Dwi, 2011, Karakteristik Penderita Demam Berdarah Dengue (DBD) di Rumah Sakit Wahidin Sudirohusodo Makassar Periode Januari-Desember 2010, Jurnal Inspirasi No XIV Edisi Oktober 2011.

Mujida A M dan Ridwan A, 2009, Pemetaan Dan Analisis Kejadian Demam Berdarah Dengue Di Kabupaten Bantaeng Propinsi Sulawesi Selatan Tahun 2009, Makassar :Universitas Hasanuddin.

Mudzakkir M, 2014, Pengetahuan Masyarakat Tentang Demam Berdarah Dengue (DBD) di Desa Kedungsari Kecamatan Tarokan Kabupaten Kediri, Jurnal Nomor 20 Volume 01.

Pelu Nunung, 2014, Karakteristik Pasien Demam Berdarah Dengue Di RSUP Dr. Wahidin Sudirohusodo Periode 1 Januari 2012-31
Desember
2012,
Makassar

UniversitasHasanuddin.

Prawirowardoyo S, 1996, Meteorologi, Bandung:Penerbit ITB.

Puskesmas Mungkid Kabupaten Magelang, 2015, Profil Puskesmas Mungkid Kabupaten Magelang tahun 2015, Magelang:Puskesmas Mungkid Kabupaten Magelang.

Purnomo A C, 2010, Dinamika Penularan Penyakit Demam Berdarah Dengue di Kecamatan Duren Sawit Kotamadya Jakarta Timur Tahun 2010, Tesis Pascasarjana Ilmu Kesehatan Masyarakat, Universitas Indonesia, Depok.

Sambuaga Joy Victor I, 2011, Status Entomologi Vektor Demam Berdarah Dengue di Kelurahan Perkamil Kecamatan Tikala Kota Manado
Tahun 2011, Manado :Jurnal Kesehatan Lingkungan ejournal.poltekkesmanado.co.id diakses pada 27 Juni 2016.

Santjaka A, 2013, Malaria Pendekatan Model Kausalitas, Yogyakarta:Nuha Medika.

Santjaka A, 2011, Statistik untuk Penelitian Kesehatan 1, Yogyakarta :Nuha Medika.

Saputra B K, 2014, Eksplorasi Spesies Nyamuk di Selokan Kecamatan Purwokerto Selatan Kabupaten Banyumas (Studi Kasus Pada

Perumahan Teluk) Tahun 2014,

Purwokerto:Kementerian Kesehatan RI Politeknik Kesehatan Kemenkes Semarang Jurusan Kesehatan Lingkungan.

Soegijanto S, 2006, Demam Berdarah Dengue Edisi 2, Surabaya:Airlangga University Pers.

Soegijanto S, 2007, Kumpulan Makalah Penyakit Tropis dan Infeksi di Indonesia Jilid 6, Surabaya:Airlangga University Pers.

Sucipto Cecep Dani, 2011, Vektor Penyakit Tropis, Yogyakarta: Gosyen Publishing.

Suhendro dkk, 2006, Demam Berdarah Dengue, Buku Ajar Ilmu Penyakit Dalam Jilid III Edisi IV, Jakarta:Departemen Ilmu Penyakit Dalam FKUI.

Susanna D, 2005, Dinamika Penularan Malaria di Ekosistem Persawahan, Perbukitan dan Pantai

(Studi di Kabupaten Jepara, Purworejo dan Kota Batam ), Jakarta:Disertasi Program Doktor Ilmu Kesehatan Masyarakat Universitas Indonesia.

Upik Kesumawati dkk, 2012, Aktivitas Nokturnal Vektor Demam Berdarah Dengue di Beberapa Daerah di Indonesia, Jurnal Entomologi Indonesia April 2012 Vol 9 No.1, 1-6.

Veronica D A, 2014, Studi Faktor-Faktor Lingkungan Fisik Rumah Penderita DBD di Wilayah Kerja Puskesmas Purwokerto Selatan Kabupaten BanyumasTahun 2014 , Purwokerto:Kementerian Kesehatan RI Politeknik Kesehatan Kemenkes Semarang Jurusan Kesehatan Lingkungan.

WHO, 2001, Panduan Lengkap Pencegahan dan Pengendalian Dengue dan Demam Berdarah Dengue, Jakarta:Penerbit Buku Kedokteran EGC.

Zainudin, 2003, Analisis Spasial Kejadian Penyakit Demam Berdarah Dengue (DBD) di Kota Bekasi Tahun 2003, Tesis Pascasarjana Ilmu Kesehatan Masyarakat, Universitas Indonesia, Depok.

Zulkoni A, 2010, Parasitologi, Yogyakarta :Nuha Medika. 